\begin{tabular}{|l|l|l|l|l|}
\hline Cuadernos de Investigación Geográfica & 2002 & $N^{\circ} 28$ & pp. 7-13 & ISSN 0211-6820 \\
\hline
\end{tabular}

(C) Universidad de La Rioja

\title{
EFFECTS OF IRRIGATION ON WATER SALINIZATION IN SEMI-ARID ENVIRONMENTS. A CASE STUDY IN LAS BARDENAS, SPAIN
}

\author{
T. LASANTA ${ }^{(1)}$ \\ W. MOSCH ${ }^{(2)}$ \\ M.C. PÉREZ RONTOMÉ (1) \\ A. NAVAS ${ }^{(3)}$ \\ J. MACHÍN ${ }^{(3)}$ \\ M. MAESTRO ${ }^{(1)}$
}

(1) Instituto Pirenaico de Ecología (CSIC). Apdo. 202, 50080-Zaragoza, Spain. E-mail: fm@ipe.csic.es

(2) Centro de Edafología y Biología Aplicada del Segura (CSIC). Apdo. 4195-Murcia, Spain.

(3) Estación Experimental de Aula Dei (CSIC). Apdo. 202, 50080-Zaragoza, Spain.

ABSTRACT: In this work, we analyse the salt and sediment load from an irrigation area located in a semi-arid environment in the Ebro Valley (Bardenas, Zaragoza). The results show higher solute and sediment load in the waters exiting the irrigation area compared to the inputs waters. Changes in the suspended load are very small, and most of the increase corresponds to soluble salts. During the period of irrigation, solute con centration is lower than during the non-irrigation periods because of higher dilution. However, the total load output during the irrigation periods is greater because the irrigation flows and returns are also higher.

RESUMEN: Se estudia la exportación de sales y sedimentos en una cuenca de regadio de ambiente semiárido en Bardenas (Zaragoza). Los resultados muestran un incremento de sedimentos en el agua de salida de la cuenca respecto a la de entrada, correspondiendo mayoritariamente a sales disueltas y muy poco a material en suspensión. Durante el periodo de riego la concentración de sales es más baja que en los días sin riego, debido a una mayor dilución, si bien las pérdidas totales son superiores en la fase de riego en relación con un caudal de retorno mucho más elevado.

Key words: salts, sediments, irrigation, semi-arid environment, Bardenas, Ebro Depression (Spain).

Palabras clave: Pérdida de sedimentos, Sales, Regadío, Ambiente semiárido, Bardenas, Depresión del Ebro, España.

\section{Introduction}

Most of new irrigation areas in Spain are located in semi-arid or arid environments, like the central Ebro Depression, with saline and/or sodic soils, which have negative 
environmental consequences (Machín et al., 1995). The high amount of salts in solution deteriorates water quality and causes salinization problems on irrigation fields downstream that re-use the water, and on the fauna and vegetation of rivers (Porta and Boixadera, 1988). Szabolis (1989) indicated that more than 10 million ha of irrigation fields are abandoned yearly because of salinization problems.

In the Ebro Depression the salinity of soils and water is an important environmental and economical problem, caused by the combination of both saline or gypsiferous materials and the semi-arid climate (e.g. Alberto et al., 1986; Navas, 1991, Golley and Bellot, 1991). The aim of this work was to quantify the amount of salts and sediments that is supplied from an irrigation area comprising two periods of irrigation and one of non irrigation.

\section{Study area}

The study was carried out in the irrigation polygon 27 of the Bardenas I system (Zaragoza). This polygon has a surface area of 643 ha (Figure 1). Climate is Mediterraneancontinental. In the meteorological station of Santa Anastasia precipitation of $423.5 \mathrm{~mm} \mathrm{y}^{-1}$ is recorded. Mean temperatures are $14{ }^{\circ} \mathrm{C}$, and potential evapotranspiration values in the studied polygon are between 1070 and $1140 \mathrm{~mm} \mathrm{y}^{-1}$ (Martínez Cob et al., 1998). Several geomorphological units can be distinguished and are described in Lasanta et al. (1999).

The area without cultivation occupies 213 ha, and is located in the sector that is affected by gullies. This part has bare surfaces and also typical vegetation of semi-arid

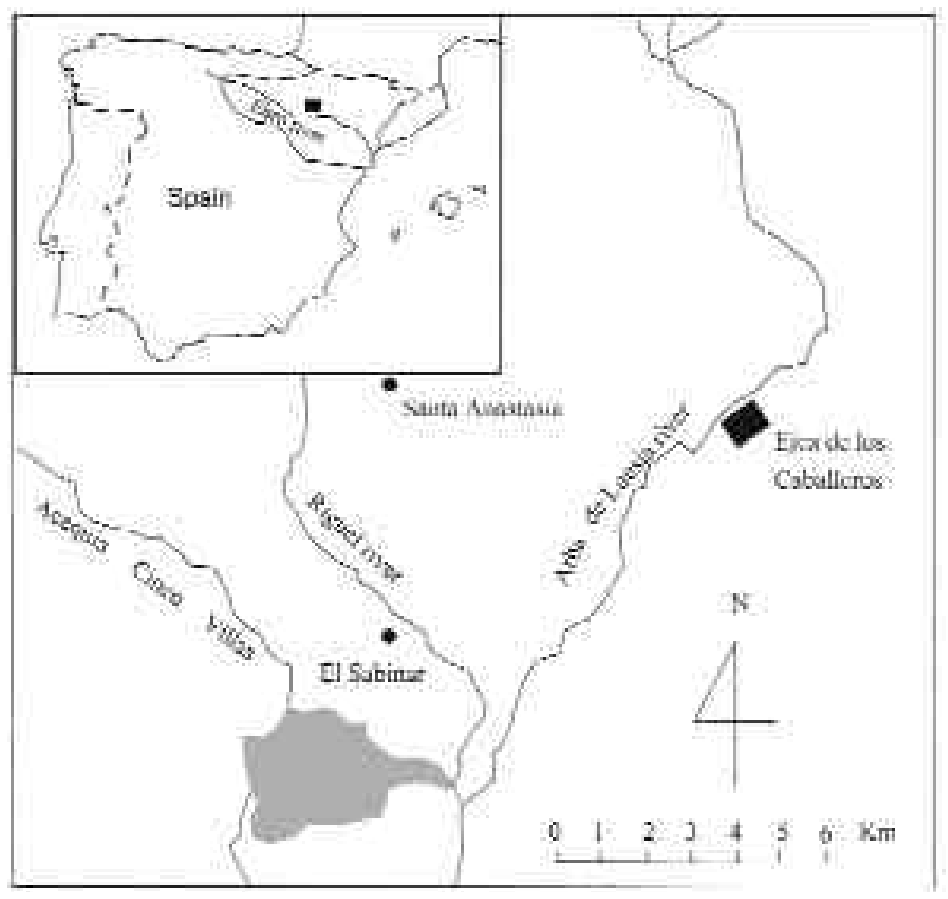

Figure 1. The study area. 
areas (Rhamnus lycioides, Brachypodium ramosum, Helianthemun pilosum, Thymus vul garis, Salsola vermiculata, Lavandula latifolia); some slopes are covered by reforestation of pine trees. The other 433 ha have been in use for irrigation since 1959, mainly for forage crops.

\section{Methods of research}

Precipitation data was taken from the meteorological station near Santa Anastasia (9 $\mathrm{km}$ from the study area). Discharge values of daily irrigation were obtained from the office of the Confederación Hidrográfica del Ebro in Sádaba (Zaragoza).

Water sampling was carried out during 16 months (from June 1999 until September 2000). It comprises two irrigation periods (from mid April until mid October), and a period without phases of irrigation (mid October until mid April). Irrigation water is supplied by the «Cinco Villas» channel and is distributed over the catchment by 7 irrigation ditches («acequias»). Water samples were taken every 13 days, totally 37 sampling days. The samples were taken in 14 sampling points (Figure 2), two of them are located respectively in the main input channel, and at the output channel at the confluence with the

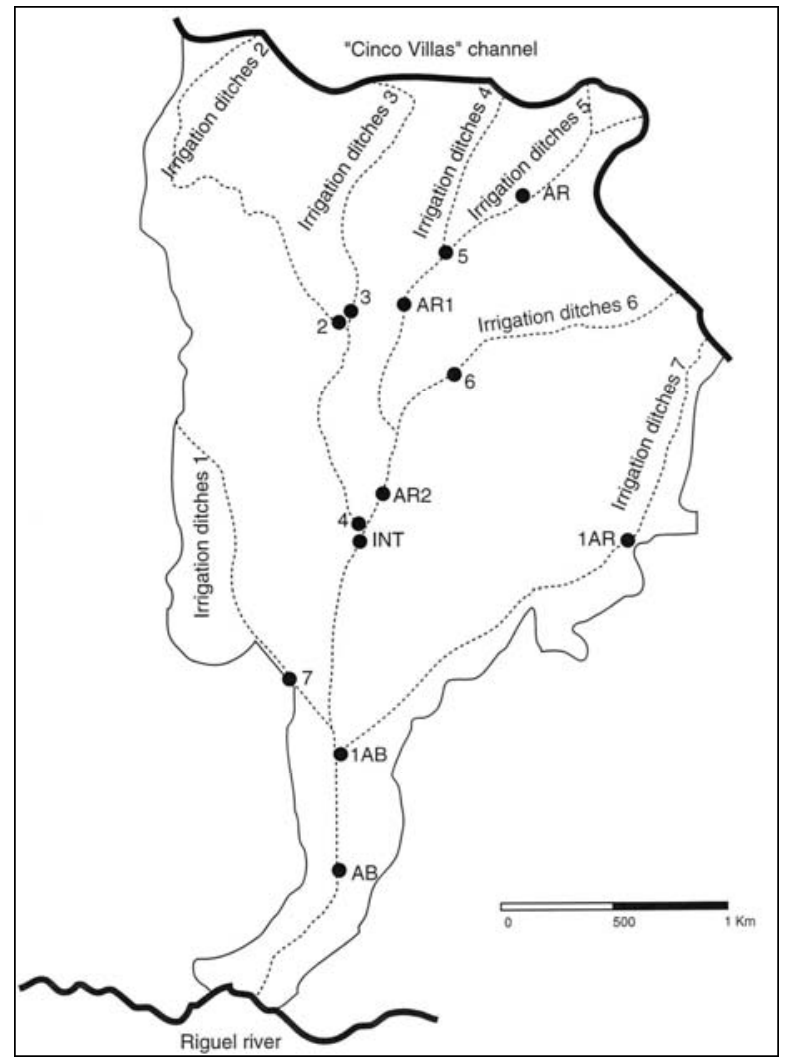

Figure 2. Location of the sampling points. 


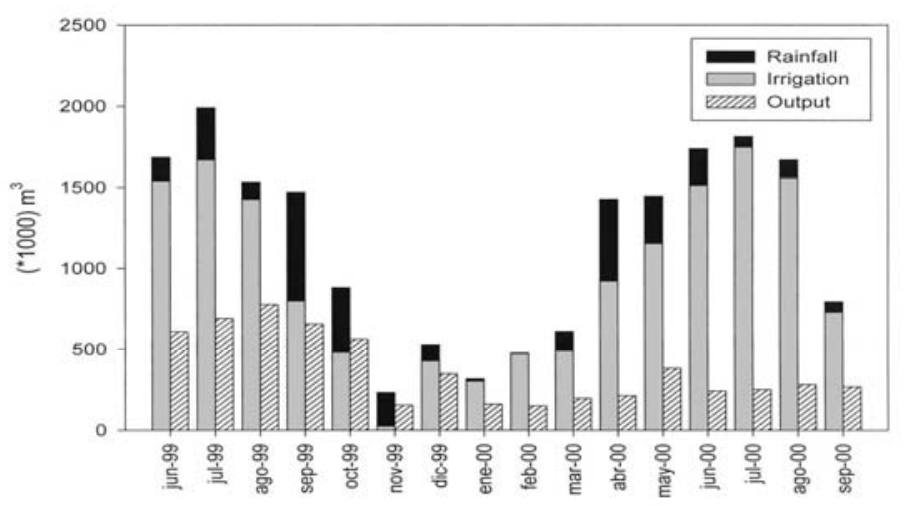

Figure 3. Water inputs from rainfall and irrigation in the catchement.

Riguel river, which receives the water outputs of the polygon. In this point the discharge measurements were carried out, using the «velocity-area» method (Shaw, 1983). The other 12 sampling points were strategically distributed over the collecting channels.

\section{Results}

Total water input was $18.61 \mathrm{hm}^{3}$ during the study period, as can be seen in Figure 3, the water input due to rainfall was $3.35 \mathrm{hm}^{3}$ and that from the irrigation channel was $15.25 \mathrm{hm}^{3}$, of which approximately one third $\left(6.28 \mathrm{hm}^{3}\right)$ left the polygon as return flow. For the hydrological year (from October 1999 until september 2000) the discharge of the return flow was $26.5 \%$ of the total water input (water input was $13.40 \mathrm{hm}^{3}$ and output $\left.3.55 \mathrm{hm}^{3}\right)$.

The discharges of the return flows varied between 0.29 and $0.054 \mathrm{~m}^{3} \mathrm{~s}^{-1}$. A strong relationship was observed between the input and output flows. The highest return flows were recorded during the months with largest water inputs. During the study period the main collector always carried water, including days without rain and without irrigation coming from rice fields that supply water continually.

The amounts of salt and sediments in the rainwater, input water of the irrigation channel and output water in main collector (point AB) is shown in Table 1. The sus-

Table 1. Average concentrations of salts and sediments

\begin{tabular}{|c|c|c|c|}
\hline & $\begin{array}{c}\text { EC } \\
\mu \mathrm{S} \mathrm{cm}^{-1}\end{array}$ & $\begin{array}{c}\text { Sediment } \\
\text { mg L L }^{-1}\end{array}$ & $\begin{array}{c}\text { Solutes (tds) } \\
\mathrm{mg} \mathrm{L}^{-1}\end{array}$ \\
\hline Rainwater & 39.80 & 5.38 & 120.56 \\
\hline Channel & 302.93 & 18.23 & 304.87 \\
\hline$A B$ irrigation & 3071.60 & 41.78 & 2261.77 \\
\hline$A B$ non irrigation & 5561.43 & 40.13 & $3919.00 \mathrm{~m}$ \\
\hline$A B$ total & 3542.65 & 41.47 & 2651.09 \\
\hline
\end{tabular}


pended sediment underwent a moderate increase (it multiplied 2.3 times). In contrast, the salt load multiplied 18.7 times with respect to the rainwater, and 7.4 with respect to the input irrigation water. Total losses are about $15.2 \mathrm{t} \mathrm{ha}^{-1}$ year $^{-1}$, of which $15 \mathrm{t} \mathrm{ha}^{-1}$ year-1 correspond to solutes and only $0.2 \mathrm{t} \mathrm{ha}^{-1}$ year $^{-1}$ are sediment in suspension. During the irrigation period losses of material are $8.08 \mathrm{t} \mathrm{ha}^{-1}$ (57.9\% of total losses) while during the rest of the year $6.4 \mathrm{tha}^{-1}$ are exported.

A Cluster analysis was carried out for identifying the possible sources of salt load. The main irrigation input channel and point 2 were excluded because of their respectively extremely low and high values. The analysis shows that 3 groups can be identified (Figure 4).

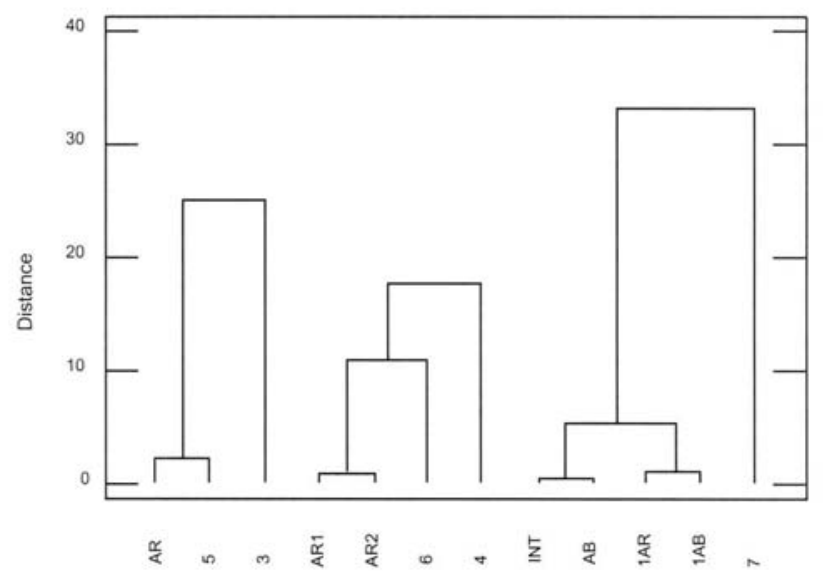

Figure 4. Cluster analysis of ion concentrations in the sampling points.

Group I is formed by points AR, 5 and 3. Land use is characterised by natural vegetation, inserted between areas with bare soils and alfalfa. Immediately above point 3 several abandoned fields are present, because of the high salt contents of the soil. This group has a high conductivity $\left(\geq 5000 \mathrm{mS} \mathrm{cm}^{-1}\right)$.

Group II includes points AR1, AR2, 6 and 4, which receive water from the central part of the catchment. Around point 6, natural vegetation is predominant, with extended zones of bare soils. On the pediment surfaces II and III, alfalfa is the most abundant crop. This is similar for points AR1 and AR2. In this group the values for EC are the lowest ones as well as the material in suspension.

Group III is formed by 5 sampling points (INT, AB, 1AR, 1AB and 7). They are situated in the lower parts of the catchment. The cultivation is almost exclusively rice. Values for conductivity are intermediate between group I and group II (the extremes of the mean values are 2757 and $4463 \mathrm{mS} \mathrm{cm}^{-1}$ ). 


\section{Discussion and conclusions}

The results of this study indicate that irrigation management has little efficiency. More than a quarter of the water input for irrigation leaves the polygon as return flow. Both rain and irrigation input waters are of high quality $\left(303 \mathrm{mS} \mathrm{cm}^{-1}\right)$ whereas output water has a mean value of $3543 \mathrm{mS} \mathrm{cm} \mathrm{cm}^{-1}$. This high value is due to dissolution of salts as the irrigation water flows through the catchment. It is well documented in the literature that return flows from irrigation cause a loss of quality of the water that is used downstream, or that returns to the river (Machín et al., 1996).

The increase in conductivity during the period without irrigation is caused by the smaller discharges of outflow and the relative higher contribution from uncultivated during this phase. An inverse relation exists between discharge and salt concentration, which is evident in irrigated areas in semi-arid environments (Wichelns and Nelson, 1987; Harker, 1983). But also it has to be considered that soils in uncultivated areas contain more salts than in the cultivated ones. The high discharge values of the return water and its high concentration suppose important losses of material. The estimated figure of $15.2 \mathrm{t} \mathrm{ha}^{-1} \mathrm{y}^{-1}$ is similar to the value of $13.6 \mathrm{t} \mathrm{ha}^{-1} \mathrm{y}^{-1}$ obtained by Basso (1994) in the same catchment for the hydrological year 1991-1992.

As much as $98.6 \%$ of the total amount of exported material correspond to dissolved material, while only $1.4 \%$ are sediments in suspension. The spatial differences in conductivity could be explained by the relative higher contribution from uncultivated soils (saline and sodic soil type) in group I, compared to group III, were rice predominates as mono-cultivation. The rice fields tend to reduce the conductivity of the water as a consequence of the high discharges of the return flows.

\section{Acknowledgements}

This study has been supported by: "Water resources management in a changing environment: the impact of sediment on sustainability" (WARMICE, ENV 4-CT98-0789), (Comisión Europea, Dirección General XII); "La identificación de fuentes de sedimento y áreas generadoras de escorrentía en relación con los cambios de uso del suelo" CICYT (REN2000-1709-CO4-01/GLO). "La recuperación del espacio agrícola como estrategia de gestión integrada del territorio en áreas de montaña: El ejemplo de los Altos Valles del Aragón y del Gállego" DGA(P049/2000). "Los retornos salinos del sistema de riego Bardenas I y su contribución a la salinización de las aguas superficiales" CICYT (Nat 90-1077 - CO2-O2). "Impacto ambiental del regadío de Bardenas I. Fuentes de contaminación y transporte de nutrientes en los efluentes de riego" CICYT (HID. 96-1306).

\section{References}

Alberto, F., Aragüés, R. and Quilez, D. (1986). Balance de sales de la cuenca del Ebro. En: Sistema Integrado del Ebro. Estudio interdisciplinar Zaragoza (España), 279-291. 
Basso, L. (1994). Los retornos salinos del polígono de riego de Bardenas I y su contribución a la salinización de los ríos Arba y Riguel. Tesis Doctoral. Universidad de Zaragoza, 2 tomos.

Golley, F.B. \& Bellot, J. (1991). Interactions of landscape ecology, planning and design. Landscape and Urban Planning, 21, 3-11.

Harker, D.B. (1983). Characteristics, trends and surface water quality implications of the saline effluent. En: Salinity in watercourses and reservoirs (R.H. French, ed.). Butterworth Publishers, Boston.

Lasanta, T., Mosch, W., Pérez Rontomé, M.C., Maestro, M. and Machín, J. (1999). Variabilidad espacial de la pérdida de solutos en un polígono de regadío de Bardenas durante una campaña de riego. Cuadernos de Investigación Geográfica, 25, 25-44.

Machín, J., Basso, L. and Navas, A. (1995). Salinity of the return flows from a pilot basin in the Bardenas I irrigation project. ESSC Meeting. The soil as a strategic resource: Degradation processes and conservation measures. La Laguna. Tenerife.

Machín, J., Navas, A. and Tardos, J.M. (1996). Niveles de nitrato en los retornos de riego de Bardenas I y su influencia sobre la calidad del río Arba. En: Agua y Medio Ambiente II (TIASA, ed.), 255-260.

Martínez Cob, A., Faci, J.M. and Bercero, A. (1998). Evapotranspiración y necesidades de riego de los principales cultivos en las comarcas de Aragón. Institución Fernando el Católico, Zaragoza (España) 223 pp.

Navas, A. (1991). The pattern of gypsum transport in the Ebro river network. Catena, 18, 45-49.

Porta, J. and Boixadera, J. (1988). Suelos y salinidad en el valle del Ebro. En: The basis of Grop Production (Ranagosa et al., eds.). AEAL, 177-201, Barcelona.

Shaw, E.M. (1983). Hydrology in Practice. Van Nostrand Reinhold (U.K.). Co. Ltd, 569 pp.

Szabolis, I. (1989). Salt affected soils. Boca Ratón, FL: CRC press

Wichelns, D. and Nelson, D. (1987). Empirical analysis of salt and selenium concentrations in subsurface drainage water. USCID, National Meeting-1987, 109-118. 